\title{
SnapLog
}

\section{- en performativ forskningsteknologi, eller hvad grævlingelorten fortæller om lærertrivsel}

\author{
Pia Bramming, Birgitte Gorm Hansen \& Kristian Gylling Olesen
}

SnapLog er en sammentrækning af 'snapshot' og 'logbog'. SnapLog er en visuel metode inden for kvalitativ forskning, der aktiverer feltet i forskningsprocessen ved at sætte feltets deltagere til at tage billeder af deres arbejde, imens de arbejder og samtidig føre logbog om deres arbejde med udgangspunkt i billederne. Afsættet for SnapLog er, at forskning gennem sine måder at spørge på rammesætter vilkårene for viden, og at disse vilkår tilsvarende rammesætter feltets mulighed for aktivt at medkonstruere denne viden. Dette har konsekvenser for arbejdsmiljøforskningen, idet denne med sit grundlæggende ønske om at forbedre arbejdsmiljøet i sidste ende har et normativt sigte og derfor hverken (kan) antage at være værdifri eller uden påvirkning af det udforskede.

\section{Nye arbejdsmiljøproblematikker behøver nye metoder}

I 70'erne og 80'erne startede en transformation af det, vi normalt talte om som 'de traditionelle arbejdsvilkår' (Allvin \& Aronsson 2003). De tidligere absolutte reguleringer af arbejdets tid og rum er under forandring, således at medarbejdernes personlige engagement og ansvarsbevidsthed $\mathrm{i}$ højere grad bliver forudsætningerne for at indgå i arbejdsforhold (Allvin \& Aronsson 2003). De ledelsesteknologier, som offentlige og private virksomheder benytter, har da også til hensigt at fremme netop denne ansvarstagning. Et eksempel på dette er elevplanen i folkeskolen, der har som formål at hjælpe lærere til at udvikle elevernes faglighed samtidig med, at lærerne skal tage ansvar for den enkelte elevs læring (Grønbæk 2009; Olesen K.G. m.fl. 2009). Elevpla- nen gør det netop, som Allvin og Aronsson (2003) generelt gør opmærksom på, vanskeligt at isolere vilkår i arbejdsmiljøet fra de personlige idealer og evner hos medarbejderen. Arbejdsmiljøproblemer bliver på den måde ikke kun knyttet til arbejdsmiljøet forstået som risikofaktorer i form af manglende muligheder for kontrol og krav, der opleves som angreb på den professionelle autonomi. Arbejdsmiljøproblemer finder også nye dagsordner i organisationen, når de fx oversættes til trivselsproblemer, hvor ledere og medarbejdere løbende skal forholde sig til, hvorvidt de trives hver især og med hinanden. Trivsel er på denne måde et godt eksempel på et aspekt af arbejdsmiljøet, der ikke knytter an til eksponering fra miljøet og effekt på personen, men bliver et spørgsmål som medarbejderne løbende må tage op og forholde sig selvledende til: at leve sundt, lære at sige nej, lære at hjælpe 
andre osv. Andre forskningsprojekter og analyser peger på, at udviklingen mod selvledelse synes at gøre trivsel til et komplekst problem, som medarbejderen i øget grad skal løse i forhold til sin egen produktivitet (Pedersen 2008; Limborg 2002; Rose 1999). Ifølge Semmer (2006) viser flere undersøgelser også, at der ikke er entydige sammenhænge mellem tilfredshed, trivselsindsatser og resultater af trivselsindsatsen.

I denne artikel vil vi præsentere en eksperimentel metode som vi kalder SnapLog. SnapLog er en sammentrækning af 'snapshot' og 'logbog' og kan kort beskrives som en visuel metode inden for kvalitativ forskning, der aktiverer feltet i forskningsprocessen ved at sætte feltets deltagere til at tage billeder af deres arbejde, mens de arbejder og samtidig føre logbog over deres arbejde med udgangspunkt i billederne. Det visuelle og skriftlige materiale bliver derefter brugt som basis for fokusgruppeinterviews. Vi afprøver SnapLog i flere projekter ${ }^{1}$, men tager her afsæt i projektet: Trivsel, Produktivitet og Selvledelse (TRIPS) ${ }^{2}$, der undersøger, hvad udviklingen mod selvledelse betyder for forholdet mellem trivsel og produktivitet $^{3}$ og har til formål at skabe viden om, hvilken betydning selvledelse som organiseringsform har for arbejdsmiljøet. Dette undersøges $\mathrm{i}$ forhold til tre udviklingstendenser i henholdsvis ledelsesteknologier, medarbejderopfattelser og selve arbejdet. Det var planlagt, at projektet skulle spænde over tre forskellige virksomhedstyper (finans, folkeskole og global service). På grund af finanskrisen viste det sig dog umuligt at entrere med finanselle virksomheder. TRIPS projektet har en varighed på tre år og er cirka halvvejs i forløbet på nuværende tidspunkt.

I første runde af vores undersøgelser udleverer vi et kamera, en fotoopgave samt information om 'SnapLog-etik' til 2x5 folkeskole lærere i to folkeskoler. I de projekter, hvor vi bruger SnapLog som metode, beder vi medarbejderne om til hvert billede at skrive 1 . hvad billedet forestiller, 2 . hvorfor de tog billedet og 3 . hvad det havde med den opgave, der blev stillet at gøre. Efterfølgende sender de billederne (snapshotdelen) og det skrevne (logbog-delen) til os. I en skole, hvor vi gennemfører SnapLog, lyder den første opgave:

"Du skal illustrere med billeder, hvad du oplever som et godt arbejdsmiljø. Du skal altså tage billeder af de ting, som du synes giver dit arbejde voerdi, som fungerer godt og som giver dig lyst til at gå på arbejde."

SnapLogs fungerer efterfølgende som afsæt for fokusgruppeinterviews, hvor fotografer og kolleger til fotograferne diskuterer billeder og loggene. Vi formulerer bevidst opgaven meget bredt og positivt ud fra vores erfaringer med SnapLog i andre projekter, hvor vi på den ene side har oplevet, at ledelser generelt ikke er så interesserede i, at der pustes for meget til, hvad der opleves som dårligt på arbejdspladsen, på den anden side, at fokusgruppedelen af SnapLog rigeligt kompenserer og giver et mere nuanceret billede af organisationen. Set $i$ bakspejlet ville formuleringen "Tag billeder af det, du synes giver dit arbejde voerdi, som fungerer godt, og som giver dig lyst til at gå på arbejde" have været mere passende, da det ikke ville mudre opgaven med fotografernes forudfattede meninger om, hvad der ligger i begrebet 'arbejdsmiljø' .

Billederne, loggen og det efterfølgende fokusgruppeinterview gør det muligt at kombinere det valgte emne - SnapLog opgaven - med studier af betydningsdannelse i gruppeinteraktion, en høj grad af interaktion blandt deltagerne og mindre styring fra forskeren undervejs (Halkier 2008). Hensigten er at skabe et rum, hvori medarbejdere ikke blot diskuterer deres opfattelser af, hvordan deres arbejdsvilkår er, men skaber 
nye diskursive praksisser om de fænomener og vilkår, de oplever som betydningsfulde for det gode arbejdsmiljø. Arbejdsmiljøet bliver så at sige intensivt 'performet' i fokusgruppeinterviewet, da fokusgrupper i sig selv er med til at forhandle fænomener som fx trivsel i nuet (Demant 2005; Halkier 2008). Formålet med SnapLogs og fokusgruppeinterviews er at få deltagerne til at tale om det, der ligger 'mellem linjerne', som får betydning for det gode arbejdsmiljø. Billederne foranlediger beskrivelser og vurderinger af det beskrevne $i$ et socialt samspil, hvor lærerne med afsæt i billeder og logs stiller hinanden materielt og diskursivt til regnskab, for det de gør og siger.

I denne artikel trækker vi på erfaringerne fra den del af TRIPS-projektet, der forsker i folkeskoler ${ }^{4}$. Indledningsvist blev denne del etableret gennem en kontakt til Danmarks Lærerforening, hvor arbejdsmiljørådgiverne motiverer deres ønske om deltagelse med, at de konkrete arbejdsmiljøproblemer og vilkår, de rammes af, ikke kan rummes inden for de sproglige muligheder, de oplever at have til rådighed. Lærerforeningens arbejdsmiljørådgivere fortæller, at de lærere, de kommer i kontakt med, oplever et socialt pres for engagement, der for det meste opleves som positivt. Altså at man villigt engagerer sig i fællesskabet, opgaverne, ledelsen af teamet og samarbejdet med forældrene. Når lærerne så bliver ramt af stress, kontakter de lærerforeningen, der så primært kan tilbyde løsningsmodeller, der retter sig mod den enkelte (af typen 'lær at sige fra-kurser' ), der netop etablerer relationen mellem lærer og arbejdsplads som en ydre relation. De sproglige og værktøjsmæssige muligheder, man har til rådighed, synes ikke at kunne rumme og indfange det sociale felt, lærerne befinder sig i. Det, man kan tale om og gøre noget ved, sker ud fra en individuel optik, hvor grænserne for deltagelse og engagement skal trækkes af den enkelte lærer selv, samtidig med at forventningerne om at deltage socialt og engageret er uafgrænselige. Det kan fx komme til udtryk ved, at lærere melder sig raske for tidligt efter sygdom, fordi de ikke bryder sig om at bebyrde allerede overbebyrdede kolleger. Lærere, der rammes af stress eller mistrivsel, opleves af lærerforeningen at 'ramme en mur': De går fra at give sig hen til fællesskabet og trække store veksler på sig selv, fordi systemet ikke giver rammer eller muligheder for at sige fra på en engageret måde. Det, lærerforeningen ønsker sig af TRIPS-projektet, er en udvidelse af de sproglige muligheder, således de bedre kan indfange det skisma, at stress opleves individuelt, men opstår i en social sammenhæng i og med, at person og arbejdsmiljø ikke længere kan afskilles.

\section{SnapLog skaber sprog og begreber}

I forsøget på at møde dette behov for at udvide de sproglige muligheder har vi ladet os inspirere til at kombinere visuelle metoder som photo-elicitation og 'autofotografering' (Harper 2002; Hurdley 2007; Warren 2008) med mere sprogligt orienterede metoder som fokusgruppeinterviews (Halkier 2008) og logbogsførsel (Kaiser m.fl. 2007). At bruge visuelle medier i kvalitativ forskning er ifølge Harper et godt bud på, hvordan man kan arbejde med at give feltets deltagere alternative måder, hvorpå de kan forstå og tale om deres sociale eksistens (Harper 2002). At introducere visuelt materiale i interviewet giver adgang til andre dele af den menneskelige bevidsthed. Metoden genererer således ikke bare flere slags data for forskeren at analysere, men også en helt anden slags data end dem man får $\mathrm{i}$ et rent verbalt interview (Harper 2002; Warren 2002). Photo-elicitation er en sådan visuel metode, hvor forskeren præsenterer fotografier i det 
kvalitative forskningsinterview, for på den måde at række ud over det interviewpersonen ville kunne levere gennem ord alene. Oftest er der her, i modsætning til SnapLog, tale om billeder, som forskeren selv har taget igennem sit feltarbejde. Kombinationen af visuelle og verbale metoder ser ud til at kunne være en god indgang til at studere et fænomen, hvor forsker og felt ønsker at udvide begrebsapparat og sprog.

SnapLog trækker på traditionen fra Photoelicitation, idet den kombinerer fotografiet med logbogen og fokusgruppeinterviewet. Håbet er, at vi gennem SnapLog kan komme til at indkredse de vilkår lærere trives og er produktive under, fordi de tager billeder af, hvad de værdsætter i arbejdet, og i dialog med kolleger og forskere giver disse billeder anledning til at sætte ord på mere generelle vilkår i lærerarbejdet, som trivslen knytter an til. Pointen med billederne er at udfolde ikke sprogligjorte praksisser, for dermed at udgøre et råmateriale, hvorfra der kan knyttes an til nye diskursive prakssiser, der kan gøre os klogere på, hvad forholdet trivsel og produktivitet bliver til i lærernes praksis. Fokus er hermed ikke på at afdække eller repræsentere feltet, men at understøtte feltet i sin skabelse. Vi placerer dermed SnapLog som en performativ teknologi.

\section{Visuelle metoder som performative teknologier}

Lad os først kontekstualisere SnapLog som en visuel, performativ teknologi: I den samfundsvidenskabelige forskning er det at 'se' og 'observere' traditionelt blevet forbundet med ingen eller en lav grad af påvirkning af det undersøgte, objektivitet, upartiskhed og ønsket om at forstå. Et sådant beskrivende fokus' modbillede vil være den normative, intervenerende forskning, der rører ved, manipulerer, eksperimenterer og påvirker feltet (Fox-Keller 1996). Med baggrund i konkrete erfaringer med brug af visuelle metoder til kvalitativ forskning, problematiserer Foxkeller dog en sådan modstilling mellem 'en ren' og en 'beskidt' form for vidensproduktion. Introduktionen SnapLog i arbejdsmiljøforskningen vil her blive brugt som et eksempel på, hvordan det, at gøre sit empiriske felt visuelt tilgængeligt, rækker ud over at give en neutral repræsentation af et uberørt empirisk felt. Brugen af visuelle metoder som SnapLog, intervenerer i feltets skabelsesprocesser og åbner mulighed for at artikulere det empiriske på alternative måder.

Vi studerer med andre ord lærernes praksisser performativt (Latour 2005); som de konstitutionsprocesser, der muliggør trivsel og produktivitet, frem for at afsøge feltet for allerede etablerede entiteter som fx krav og kontrol. At arbejde performativt med visuelle metoder er en måde at gøre praksisser, der endnu ikke kan tales om, tilgængelige for både felt og forsker. Med SnapLogs introduktion af visuelle data, forsøger vi at skabe adgang til forståelser, der ikke er velreflekterede, verbale og bevidste kategoriseringer. SnapLog er på denne måde en teknologi, der medierer det sociale, undersøger og skaber sociale transformationer, og som sådan lægger SnapLog afstand til forestillinger om sprogets akkurate repræsentationelle egenskaber (Barad 2003). Hvor repræsentationalismen fokuserer på sproglige repræsentationer og stræber efter at generere så præcise beskrivelser af det, der ønskes repræsenteret, fokuserer performativitet som forskningsparadigme på at følge feltets konstitutionsprocesser. Ifølge (Barad 2003) producerer snarere end beskriver performative diskursive praksisser videnspraksissernes vilkår. Disse vilkår er iboende og historiske snarere end transcendente eller fænomenologiske. Det vil sige, at diskursive praksisser er aktuelle, historiske situerede sociale vilkår (Barad 2003, 819). Fokus er hermed ikke at (re)producere 'rigtige beskri- 
velser' af feltets opfattelser, men at undersøge, hvad feltet gør og hvad feltet vil, når det får muligheden for at tale.

\section{Synlighed og validitet}

For forskeren sætter performativiteten et dobbelt vilkår: Idet vi følger skabelsen og konstitutionen af trivsel, og ikke trivsel som præ-etableret entitet, er vores forskningsmæssige dagsorden underlagt det samme vilkår; at man ikke kan undersøge noget uden samtidig at forstyrre/ændre det undersøgte, og at de diskursive praksisser er skabende snarere end beskrivende. I den forbindelse har post-feministisk forskning tidligere problematiseret den visuelle metafor og dens traditionelle kobling til objektiviteten og repræsentationalismen. Den særlige kobling mellem den visuelle metafor og det neutrale, registrerende upartiske videnskabelig blik er blevet kritiseret for at lave det, den amerikanske biolog, historiker og post-feminist Donna Haraway kalder et 'Gudetrick' (Haraway 1991). 'Gudetrick' er, når forskningen afbilleder det empiriske felt med blik 'oppefra', som om forskeren ser feltet igennem guds øje. I arbejdslivsforskningen vil 'Gudetricks' ifølge Haraway fx være, når store kvantitative epidemologiske undersøgelser af arbejdslivet gør feltet synligt uden at redegøre for det uomgængeligt kropslige og lokale ved det at se og repræsentere andres praksis. Når arbejdslivet ses 'oppefra' igennem Guds øje, undlader forskeren at tage ansvar for de effekter, som hans eller hendes repræsentation af feltet kan få. ${ }^{5}$

Når man således tager et kamera med i feltet, kan det være en fordel at tage en feminist med i baglommen, idet post-feministisk forskning ikke kun har kritiseret den visuelle metafor, men også forsøgt at arbejde konstruktivt med den. Haraway insisterer på at holde fast ved synet og den visuelle metafor som en produktiv påmindelse om, at al repræsentation indebærer en position, et "view from somewhere": "The only way to find a larger vision is to be somewhere in particular" (Haraway 1991, 182). Ethvert blik indebærer et par øjne, og øjnene, hvad enten de er koblet til et kamera, en diktafon eller et mikroskop, er altid en del af en krop. Fotos er således ikke at betragte som 'bevis' for, hvordan feltet i virkeligheden ser ud, men som partielle, fragmenterede og kontekstafhængige versioner af det empiriske felt (Warren 2002). Vores brug af SnapLog tager det intervenerende aspekt ved det 'at

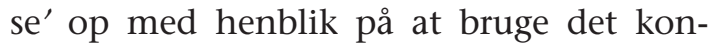
struktivt til at skabe alternative og måske nye måder, hvorpå både felt og forsker kan forstå den problemstilling, der undersøges. Intervention skal her forstås bredt som en indgriben i eller en forstyrrelse af feltet, som tillader både felt og forsker at tænke anderledes. Brugen af SnapLog skal derfor ikke gribes snævert som en interventionsmetode i betydningen, at forskeren har til hensigt at 'løse' et problem, som feltet oplever som presserende, ved at træde ud af sin egen forskerkrop og se feltet med feltets egne øjne. Den post-feministiske kritik af den visuelle metafor retter sig imod enhver påstand om, at det er muligt at overskride eller udskifte de øjne man ser med. Om det er et blik 'oppefra' (forskerblikket som guds øje) eller 'nedefra' (forskerblikket som medarbejderens perspektiv) er sådan set underordnet. De undertryktes standpunkt er ifølge Haraway ikke at betragte som et alternativ til et 'Gudetrick'. Det er hverken uskyldigt eller neutralt at "forske nedad" (Staunæs \& Søndergaard 2005) eller at påstå, at man kan se tingene gennem øjnene på den stressede vidensarbejder, den automatiserede slagteriarbejder eller den udbrændte socialrådgiver. Politisk motiveret forskning, der ønsker at give stemme til dem, som gøres tavse i feltet bør, siger Haraway (1991), også huske på, at forskeren altid kun har en partiel adgang til feltet. Øjet, der ser, sidder fast på et hoved; 
en kropslig bundethed og positionering som forskeren hverken kan overskride eller skifte ud. Fotografiet er et partielt perspektiv, der giver et blik fra én kontekstafhængig position $\mathrm{i}$ feltet $\mathrm{og}$ dermed en påmindelse om at undgå såvel 'Gudetricks' som 'underhund analyser'. Når vi tager feministerne med i baglommen i en diskussion af en visuel metode, er det for at minde os om, at det at gøre feltet synligt er en bestemt måde at interagere og intervenere på. Gennem SnapLog vil vi søge at bruge denne position konstruktivt - ikke overskride den.

\section{Den normative dimension af at arbejde performativt}

Da arbejdsmiljøforskningen i sidste ende handler om at finde måder, hvorpå arbejdsmiljøet kan forbedres, har et performativt forskningsparadigme inden for arbejdsmiljøforskningen uundgåeligt en normativ retning. Udfordringen i det performative paradigme er dermed det partielle perspektiv, der ligger i forskerens antagelser om 'det gode arbejdsmiljø'. Sådanne antagelser, hvis de er underforstående, vil styre forskningen på en i det performative perspektiv uvidenskabelig måde. Validering i den performative forskning må nødvendigvis foregå gennem overvejelser om, hvordan forskningen er performativ i et allerede performativt felt. Desuden er feltet også underlagt (egen) normativitet. I arbejdsmiljøforskningen har vi oplevet eksempler på, at medarbejdere decideret har ønsket at medvirke i projektet med henblik på at producere et så graverende materiale, at ledelsen ville kunne udskiftes på den baggrund. Der ligger altså et stort ansvar på arbejdsmiljøforskeren ikke for ikke at blive brugt (det er i perspektivet en umulig fordring), men for at overveje, hvordan forskningen bruges og virker.

I erkendelsen af at forskerens position sætter betingelserne for, hvad der kan ob- serveres og konkluderes i et givent empirisk felt, må vi nødvendigvis spørge, hvad det vil sige at bruge denne position konstruktivt (Bramming \& Frandsen 2003). Det svære spørgsmål er, hvordan man skelner mellem god og dårlig forskning i arbejdsmiljø, når man først har afstået fra at bruge 'Gudetricks' eller 'underhunds analyser' som legitimerende instans.

Her vælger vi at hente inspiration fra et felt, som i første omgang kan virke eksotisk i forhold til vores konkrete forskningsområde, men som måske netop derfor kan hjælpe os med at nytænke den normative dimension ved arbejdslivsforskning. Etologien, studiet af dyrs adfærd, har som disciplin har været nødt til at tage stilling til, hvordan man som forsker kan give stemme til empiriske fænomener, som man ikke nødvendigvis kan antage at have et sprog for. Med udgangspunkt i hvordan etologien har udviklet sig, finder forfattere som Vincianne Despret og Emile Gomart frem til en måde at skelne mellem gode og dårlige eksperimenter på. Ifølge Gomart (2004) gør god forskning feltets deltagere 'tilgængeli$\mathrm{ge}^{\prime}$ for eksperimentet, dårlig forskning gør feltets deltagere 'føjelige' og tilpasser dem de spørgsmål, som eksperimentet kræver, de svarer på (Gomart 2004). Et performativt eksperiment kan altså siges at være god forskning, når det, der studeres, får lov til at gøre sig genstridig og blive en aktør, frem for en passiv overflade som forskerens begrebsliggørelser og konstruktioner kan indskrive sig på (Haraway 1991).

Vincianne Desprets kritik af etologiens metodiske udvikling kan tjene som eksempel på denne ambition om at tillade genstandsfeltet at have status som genstridig aktør (Despret 2005). Despret redegør for, hvordan de fleste studier af dyreflokke fra begyndelsen har antaget, at dyrs adfærd handler om konkurrence og hierarki, simpelthen fordi den måde, man har synliggjort 
aber på, har været at få dem til at konkurrere om mad og/eller studere dem i brunstperioder, hvor 'der sker noget' (Despret, 2005). Et interessant bidrag inden for etologien har eksperimenteret med andre metoder at få dyrene i 'tale' på. Gennem sin læsning af Thelma Rowells studier af fårs adfærd viser Despret (2005), at forskeren ved at rejse 'spørgsmålet' på en anden måde, og derved se og observere fårene på andre vilkår, lader fårene fremstå som beherskende komplekse sociale sammenhænge. Fårene får, kan man sige, en ny stemme. Rowell opnår dette på den yderst simple måde, at hun for det første observerer fårene et helt år (og ikke kun i brunstperioden) og for det andet lader det være op til fårene selv at vælge, om de vil konkurrere eller ej (det gør hun ved at tilbyde 23 madskåle til 22 får). Fårene 'ændrer' sig fra at være enfoldige og endimensionelle fæ drevet af et simpelt overlevelsesinstinkt til at blive sociale fæ, der opretholder komplekse relationer gennem ritualer, der var usynlige for det blik, der satte konkurrence og hierarki som vilkår for forskningen. Ved at tillade dyrene at gøre andet og mere end at konkurrere og slås har etologien opdaget, at det centrale spørgsmål for de fleste dyr slet ikke handler om, hvorvidt der er nok at æde, men snarere hvordan man selv undgår at blive ædt - altså en helt anden måde at sætte problemet på. Pointen, som vi vil bringe videre ind $i$ arbejdsmiljøforskningen, er, at forskerens observationer eksperimenterer med det sete, hvilket betyder, at forskeren må fokusere på de vilkår, det at 'se' sit felt rejser for feltets deltagere, og hvilke muligheder for at gøre sig genstridig det undersøgte hermed får (Latour, 2005). Det vil sige, at der ikke er tale om en objektiv iagttagelse af en genstand. I stedet er der tale om, at forskellige rammesætninger giver forskellige vilkår for, at det undersøgte kan få en effekt på det, der kan konkluderes. Kravet til forskeren bliver at skabe klar- hed over, hvordan rammesætningen skaber (ny) viden om det undersøgte frem for at reproducere eksisterende viden. For at undgå at arbejdslivsforskningen laver samme fejltrin som etologien - ved på forhånd at kategorisere hvordan arbejdslivet kan studeres - må forskningen finde nye måder at give feltet en chance for blive aktør i forskningen og medkonstruktør af problemet på. Vores iver for at skabe et godt og bæredygtigt arbejdsmiljø kan let drukne feltet i gode intentioner og sympatiske betragtninger, som vi ikke har nogen mulighed for at efterprøve relevansen af (Latour 2005). Ambitionen er at give feltet mulighed for at fortælle helt andre historier ved at observere feltet på måder, der tillader at forskeren toenker anderledes om feltet, end vi plejer at gøre (Foucault 2004). Bruno Latour formulerer fordringen således:

"Am I asking you the right questions? Have I devised a laboratory setting that allows me to change as fast as possible the questions $i$ ask, depending on the resistance of your behavior to my questioning?" (Latour 2005, 216).

Når man eksperimenterer med moderne arbejdsliv, er det ikke det samme som at eksperimentere i et kemisk laboratorium, der som bekendt kan eksplodere, hvis man stiller et forkert eller irrelevant spørgsmål (Latour 2005). I arbejdsmiljøforskningen er det sværere at få feltet til at svare igen eller eksplodere. Problemet i den sammenhæng er grundlæggende feltets kolossale tjenstvillighed. Feltet forsøger som regel at svare på de spørgsmål, forskeren stiller, hvilket betyder, at man kan forledes til at tro, at de spørgsmål man stiller, er både gode og relevante. Dette fænomen kalder Bourdieu og Wacquant (Bourdieu 1997), at feltet bedriver 'spontan sociologi'. En skolelærer, oplever vi, svarer altid pænt ja eller nej til spørgsmålet, om de er stressede eller ej, 
men dette giver ikke omvendt, at den måde problemet sættes på og de spørgsmål, der stilles, overhovedet er relevant, eller om der er noget andet og vigtigere, som presser sig på for skolelærere i dag.

Kravet til den måde, vi igennem visuelle metoder positionerer os selv i feltet på, er således at finde en måde at spørge på, hvor feltet får en chance for at gøre andet og mere end lydigt at bedrive 'spontan sociologi' efter forskerens pibe. Med et performativt paradigme kan vi ikke antage, at vi allerede har de relevante kategorier. De relevante kategorier skal skabes, og det er konstitueringen af disse kategorier, der skal følges i feltet.

Frem til nu har vi primært fokuseret på det visuelle aspekt af SnapLog. SnapLog gør dog andet end alene at introducere det visuelle som en måde, der giver forskeren adgang til feltets kropsliggjorte, tavse og derfor mere uhåndgribelige aspekter. Ambitionen er at introducere en metode, der kan virke som Desprets 23. madskål. Derfor må forskeren og feltets deltagere samarbejde om at opfinde nye måder at artikulere feltet på. SnapLog kræver et sådant samarbejde mellem forsker og felt, og fra det lignende photo-elicitation har man oplevet en sådan 'dåseåbner effekt' (Warren 2002), hvor feltets deltagere får mulighed for at overraske forskeren og gennem en dialog om fotografierne producere nye og uventede forståelser af feltet (Warren 2002). Harper begrunder sin brug af photo-elicitation med, at denne metode netop faciliterer et samarbejde mellem forsker og felt:

"Når to eller flere diskuterer meningen af fotografier, prver de at finde ud af noget sammen. Dette er, mener jeg, en ideel model for forskning." [vores oversættelse] (Harper 2002, 23).

Til forskel fra den gængse brug af photoelicitation, hvor det er forskeren, der producerer eller udvælger de billeder, som in- troduceres i interviewet, har vi, inspireret af Samantha Warrens visuelle studier af arbejdsliv ladet feltets egne aktører fotograferer deres egen praksis (Warren 2002; Warren 2008). Det at lade feltets deltagere udvælge motiver for fotografering forstærker ifølge Warren den kollaborative effekt ved Photo-elicitation (2002)

\section{SnapLog i praksis}

I det følgende eksemplificerer vi, hvordan SnapLog er blevet brugt i TRIPS-projektet og diskuterer, hvordan metoden virker i det konkrete projekt. Vi slutter med at optegne de muligheder og problemer, der stiller sig ved brugen af metoden.

Det første, der fra et arbejdsmiljøperspektiv var interessant ved anvendelsen af SnapLog i de to folkeskoler i projektet, var det lærerne ikke fotograferede, og hvad de $i k k e$ bragte på bane. Lærerne pegede eksempelvis ikke på faktorer, som ud fra et traditionelt arbejdsmiljøperspektiv ville have været naturlige. De pegede hverken på krav, forudsigelighed eller kontrol over og i arbejdet, de talte ikke om arbejdstid, om besvær ved involvering af forældre, om personalegoder, de fotograferede ikke gode kolleger, pegede ikke på deres faglighed eller på ledelse. De peger altså ikke på de aspekter, som arbejdsmiljøforskningen, ifølge Nicolas Rose, traditionelt har forsket i som fx autonomi, og hvor det normative aspekt ofte har handlet om:

"at designe arbejdet med henblik på at maksimere autonomi, tillade udfoldelse af håndvoerkskab, at give mening ved at tillade medarbejdere at have kontrol over deres eget arbejde [vores oversættelse]" (Rose 1999, 104).

Lærernes billeder, logs og dialoger synes derimod primært at handle om, hvad der gør 
det muligt (vilkår) for dem at løse det, de oplever som deres kerneopgave; at skabe læring for eleverne; hvad der understøtter og presser denne opgave; hvad der konstituerer 'god læring', og hvordan de ser sig selv og hinanden som lærere. Vi vil i de følgende afsnit trække nogle af de SnapLogs, lærerne præsenterede, frem og diskutere disse dels ud fra den dialog, der opstod ved fokusgruppeinterviewene, dels ud fra de overvejelser, det har foranlediget blandt forskerne.

\section{Vilkår, mennesker og følelser}

Det første SnapLog, vi vil trække frem, er knyttet den måde, lærerne relaterer sig til rummet for læring.

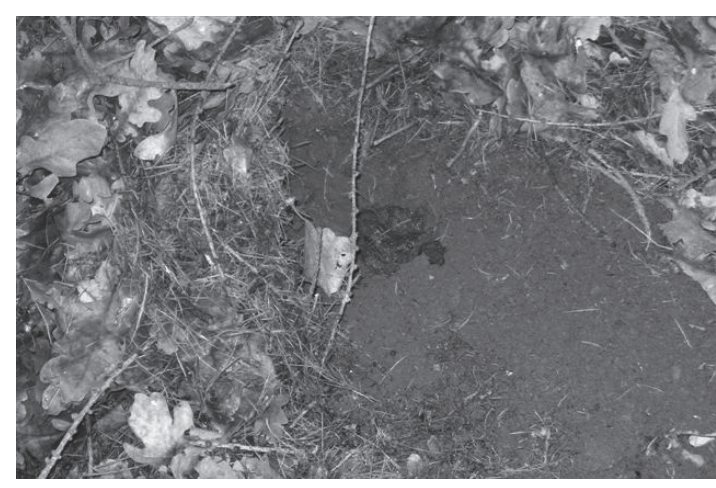

Billedet viser en graevlingelort. Groevlingen er mere doven end katten, den graver nemlig et fint lille toilet, anbringer hvad der skal anbringes, men gider ikke at slå broettet ned. (Den doekker det ikke bagefter...) Jeg er absolut et natur- og udemenneske, og elsker når jeg kan have eleverne med ud.

Da billedet af grævlingelorten blev lagt på bordet, sagde en af deltagerne spontant: " $V i$ har naturen det billige skidt, lige omkring os!". Denne begivenhed (det vil sige ikke billedet alene, men hele set-uppet omkring billede, tekst og interview) viser kompleksiteten i trivsels/selvledelsesproblematikken. For at læreren, der har taget billedet, kan trives må han eller hun undervise på en bestemt måde, der opleves som i overensstemmelse med ham eller hende. Dette foranledigede en længere diskussion om naturens betydning i lærerarbejdet og vilkårene ved at inddrage naturen som undervisningsrum. I det hele taget var der overraskende få fotos af en lærer, der underviser i et decideret klasselokale. Det lod til, at trivsel for lærerne var knyttet til ideen om at finde nye og spændende materielle rammer for undervisningen. "...det er et koempe plus, at vi bare kan lukke døren op og finde en regnorm" siger en lærer, imens en anden ler. Motivvalget er i det hele taget præget af, at lærerne har forkærlighed for og finder glæde i læringssituationer, der adskiller sig fra det, de kalder 'røv-til-sæde-metoden'.

Brugen af rummet på andre måder end den traditionelle - eller brugen af andre læringsrum gør det muligt for lærerne at opleve et positivt lærer-selv-billede, som sætter rammerne for læringssituationer, der aktiverer elevernes kreative læringsmuligheder. Lærerne oplever i høj grad at lykkes som lærer, når eleverne udfolder sig fagligt på rumligt kreative måder. En lærer reflekterer eksempelvis over nogle billeder af børn, der ligger på gulvet, under bordene med deres bøger, hvor det for læreren handler om, at setuppet skaber rum for en anden måde at være lærer på:

"Det man ikke skal sige. Man skal ikke sige: "sid nu stille på stolen", når de ligger på maven. Vi sparer stemmebåndet temmelig meget." [...] "Og børn er forskellige, nogle har det faktisk bedst under et bord, de skal loere forskellige steder. Det skal ikke foregå med røv-på-saede-metoden."

Det disciplinerede klasselokale med røv-påsæde-metoden, hvor skæld ud opretholder disciplinen, bliver her afløst af klasserummets individuelle åbning i personlige relationer mellem lærer og elever. Billederne viser, hvordan den kreative brug af rummet 'hjælper' læreren til ikke at opfylde sin mål- 
sætning om, at skabe forskellige læringsmuligheder. Når børnene leger sig ind i matematikken lykkes læreren, fordi læreren bliver bestyrket i en positiv læreridentitet som udviklende. For lærerne kommer dette visuelt til udtryk i undervisningssituationer, der ikke ligner undervisningssituationer, og som understøtter et ideal om kreativitet og udvikling, en udvikling, der hele tiden sætter den enkelte lærer på spil i centrum af begivenhederne for hver sin klasse.

\section{"Vi underviser i os selv"}

"Vi underviser først og fremmest $i$ os selv", siger en lærer og uddyber: "ikke at de skal blive enige med os eller sådan noget, men de skal sgu ha' en eller anden at spille bold op ad, og det er der sgu mange af dem der ikke får derhjemme mere" - og at dette ikke er en ny udmelding, men snarere en skamredet, men anerkendt kæphest, bliver tydeligt af de andre læreres reaktioner: " at de (...) kan finde ud af at behandle hinanden ordentligt (...) det er måske vores primoere opgave". Lærerne håndterer og taler med andre ord om (idealiserede) læringssituationer, hvor de selv og eleverne mødes ikke som ud fra en primært faglig op- tik (at de skal hælde viden på tomme kar), men en menneskelig optik, hvor lærerne er mennesker, der skal undervise (små) mennesker i al deres forskellighed. Disse relationer forhandles af 'vilkårsaktører'- i dette tilfælde de materielle aspekter af læringsrummet, der gør det muligt for lærerne at møde eleverne ud fra idealet om kreativ og udviklende læring.

En stor del af de SnapLogs lærerne har lavet, viser billeder af de børn, som lærerne underviser til daglig. Lærernes kommentarer til billederne italesætter elevernes iver, uventede fremskridt i undervisningen eller elevernes underholdende indslag.

Lærernes følelsesmæssige tilknytning til eleverne som personer synes at være en vigtig relation i lærergerningen. En lærer siger fx: "at vi ikke kan voere loerere, uden at vi har et personligt engagement, følelsesmoessigt - selvfølgelig til en vis groense." Det centrale i denne sammenhæng er, at læreren siger "til en vis graense". Læreren er traditionelt en autoritetsfigur, der behersker et fagfelt, som han eller hun skal videreformidle til eleverne. I den sammenhæng må læreren som professionel ikke lade sine egne følelser spille ind i hver-

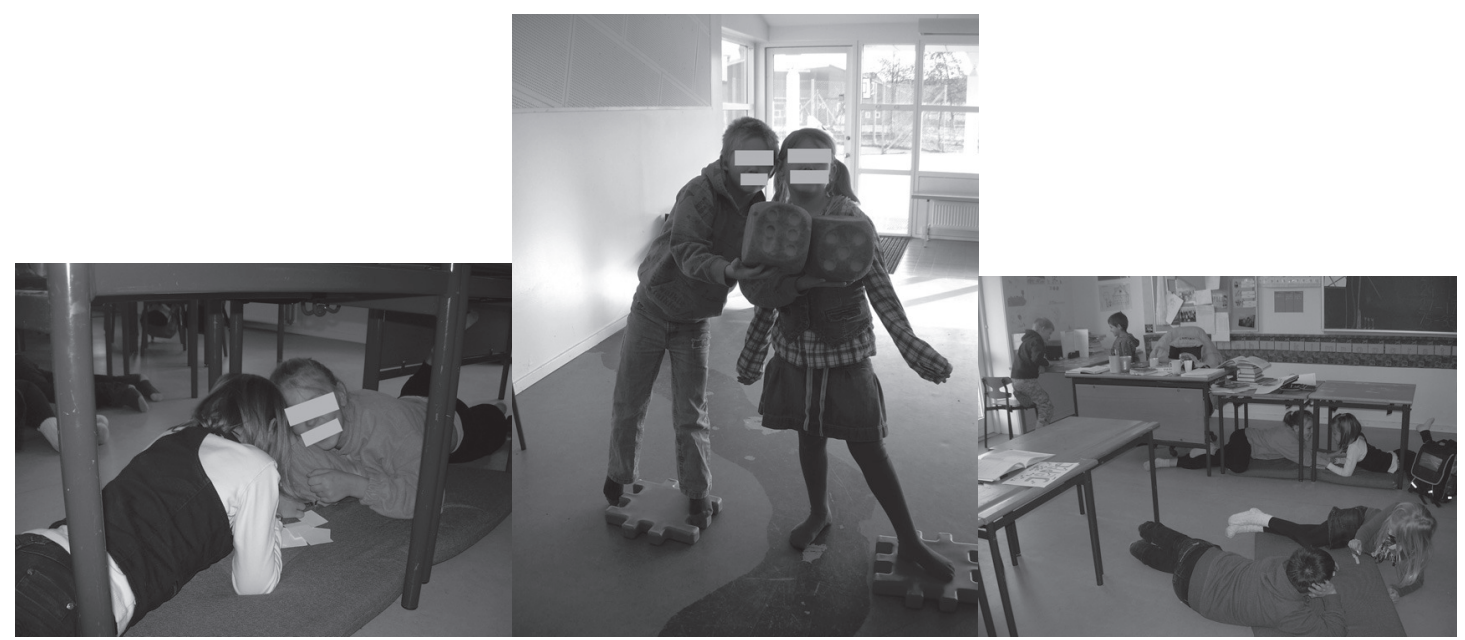

Billederne viser mine elever i forskellige loeringsrum, hvor de hygger sig med matematikopgaverne.

Jeg har taget billederne, fordi jeg bliver stolt og glad, når børnene føler matematikundervisningen som en leg og kan hygge sig med at fordybe sig. Det giver mig faglig stolthed. Det giver mig motivation at vide, jeg har styr på at strukturere timerne til stor tilfredsstillelse for både elever og loereren. 
ken vurderingen af eleven eller kvaliteten af undervisningen. Men det ville jo kræve, at læreren holdt op med at være menneske (og holdt op med at føle). Spørgsmålet for lærerne synes dermed ikke at være, hvordan de kan lade være med at involvere sig følelsesmæssigt, men hvordan de kan involvere sig følelsesmæssigt, professionelt.

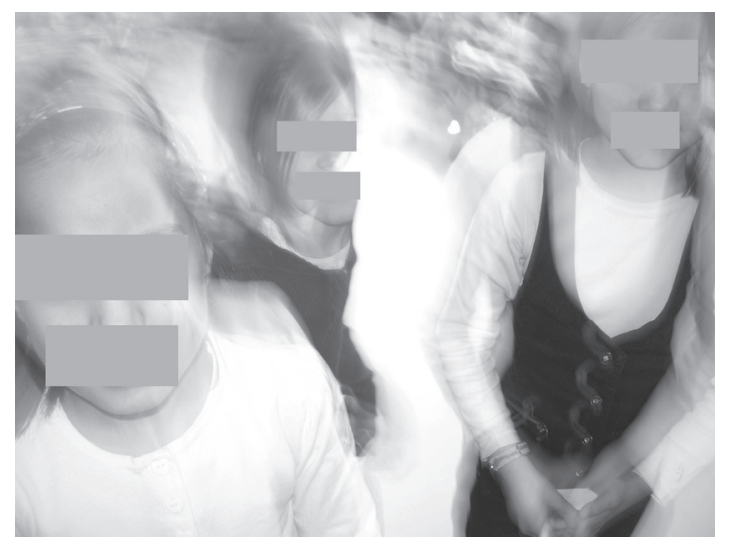

Billedet viser en masse glade børn fra min klasse, der løber mig i møde og giver et kram efter jeg har voeret fravoerende i en periode.

Jeg har taget billedet, fordi det gør mig glad. Det giver mig arbejdsgloede at vide, jeg er savnet, når jeg er voek. Det er voerdifuldt, at børn og voksne bemoerker, når man vender tilbage.

\section{Opsamling og diskussion}

De SnapLogs, som vi her giver eksempler på, hvordan vi arbejder med, fungerer som afsæt for de næste, og giver os muligheder for at præcisere, hvordan vi kan stille spørgsmål, der kan udfolde det, der her er skitseret. Udfoldningen ovenfor peger i retning af to, sammenhængende pointer. Den ene pointe er, at lærernes relationer til eleverne forhandles ud fra nogle vilkårsaktører, fx rummet, der på forskellig vis muliggør (eller hæmmer), at læreren kan lykkes med sit forehavende - at skabe kreativ, udviklende læring for den enkelte elev. Disse vilkårselever ser ud til at have det til fælles, at de betoner brugen af læringsrum på måder, der formuleres som en kontrast til en 'gammeldags autoritativ' undervisningsform. Selve formen ser ud til at kunne give lærerne en oplevelse af at lykkes eller mislykkes, og de knytter i de konkrete SnapLogs relativt entydigt en positiv læringssituation sammen med alternative brug af rummet. Man kan spørge, om det så betyder, at lærerne tror, at alle elever lærer bedst, hvis de ligger på gulvet eller sidder andre steder end på stolen. Sammenhængen er næppe så simpel, at lærerne antager, at en kreativ kropslig placering i rummet sikrer kreativ læring, mens en elev, der sidder ret op og ned på en stol ved sit bord, kun er i stand til at udenadslære. Ikke desto mindre tyder SnapLoggene på, at der i vores SnapLog opleves en højere grad af læring, når det rumlige (og kropslige) ser ud til at aktiveres. Noget af dette, kan man indvende, skyldes metoden: At SnapLog kræver billeder af gode arbejdssituationer. Understøttelsen af fokusgruppeinterviewet peger dog på, at der er et vist belæg for at hævde, at lærerne i højere grad opleves at lykkes, når vilkårene giver mulighed for individuel kropslig udfoldelse i læringssituationen.

Den anden pointe handler om lærerens personlige engagement og refleksioner om, hvordan man kan involvere sig følelsesmæssigt med eleverne på en professionel måde. Det står klart, at lærerne i højere grad oplever at lykkes med deres lærergerning, når de investerer deres personlighed i læringssituationerne og går i personlig dialog med de enkelte elever om deres læringsfremskridt. Det handler ikke blot om, at 'være sig selv', men om hvordan man kan dosere et selv på den rigtige, professionelle måde, så læring opnås. Der er med andre ord ikke fokus på den individuelle lærer, men på et præ-individuelt vilkår for at kunne blive en sådan lærer, fordi trivsel for lærerne handler om at kunne lykkes med deres forehavende. Lærere, der trives er ikke vigtige ud fra et rent humanistisk perspektiv - eller ud fra et 
egoistisk perspektiv hos den enkelte lærer. Lærertrivsel bliver et spørgsmål om at sikre, at relationen mellem lærer og elev kan blive produktiv således, at læreren lykkes som lærer, hvilket sker, når eleven er/opleves som et lærende individ.

Det, der i denne sammenhæng er væsentligt, er, at vi trækker de forhold, som lærernes praksis udpeger som rigtige og vigtige, ind i trivselsdebatten og giver denne et lokalt, partielt perspektiv. Trivsel for lærerne handler om det, deres praksis viser, det handler om. Lærernes SnapLog er som eksperimentel metode et værktøj, der tillader feltet at være genstridigt og gøre modstand mod forskerens blik.

I vores empiri performer lærerne trivsel ved at udvælge motiver, som udfordrer og supplerer fx krav/kontrol modellen (Karasek 1979). Det betyder, at vores empiri lader os ane, at krav/kontrol-modellen kan komme til at fungere på samme måde som hirearki/konkurrence-modellen fungerede i etologien. Fordelen ved at bruge SnapLog er, at den tillader lærernes praksis at blive en aktør, der kan give modstand til vores tænkning. Fotos, som viser det affektive og det relationelle ved lærergerningen, kalder på andre typer af analyse end dem, vi får stillet til rådighed ved at reducere trivsel til det, lærere kan svare, når de stilles spørgsmål om fx forholdet mellem krav og kontrol i lærergerningen. Hermed udfordres vi også til at tale om trivsel på nye måder, og vores analyser bliver søgende, famlende og mere åbne, når vi afprøver mulighederne $\mathrm{i}$ de rum, lærerne stiller foran os.

Det er denne ambition om ikke at reducere det empiriske til det, vi allerede ved, SnapLog er designet til at møde. Det, der er udgangspunkt for at studere et felt via SnapLog, er lærernes konkrete praksis, snarere end egne eller vores vurderinger af den. Eftersom vi er ude efter at lægge fundamentet for alternative sproglige muligheder for trivsel i lærergerningen, er der grund til at antage, at hverken vores eller lærernes bevidste, verbaliserede udtryk er tilstrækkelige som ressource. Trivsel kommer til orde gennem det visuelle materiale, men også gennem den konkrete performance af trivsel, som finder sted igennem fokusgruppeinterviews. Her indgår felt og forsker i et samarbejde, hvor begge parter bliver tvunget til at tænke anderledes (og det er vanskeligt for begge parter). Krav og kontrol vil være teoretiske figurer for lærerne, som de med en indsats vil kunne forbinde til deres verden på samme måde som fårene, der villigt viste tegn på konkurrence og hierarki $\mathrm{i}$ brunstperioden, samtidig er det vanskeligt for forskerne at ryste eksisterende forestillinger om trivsel af sig. Ved at inddrage fotos fra lærernes arbejde, taget af dem selv, giver SnapLog et blik på lærergerningen som andet og mere end det, forskeren havde forestillet sig, var interessant. Brugen af SnapLog får således ikke bare felt og forsker til at inddrage nye aspekter ved den praksis, som undersøges, men fordrer også, at forskeren tænker anderledes og stiller nye spørgsmål. Efter de første SnapLogs blev vi nysgerrige efter at finde ud af, hvordan lærerne bruger hinanden i deres arbejde, da dette var usynligt for det spørgsmål, vi stillede i første omgang. I vores foreløbige erfaringer med SnapLog forsøger vi at rumme den genstridighed, lærerne udviser ved insisterende at afbillede lærergerningen som det, vi her, i vores første forsøg, kan kalde faciliteringen af kreativ og udviklende læring i relation med en følelsesmæssigt engageret, men professionel lærer. Vi får indblik i, hvordan lærerne skaber mening om og eksperimenterer med at opnå dette ideal. Dette ser vi som en begyndelse til nye måder at kunne spørge til og tale om trivsel, måder hvor lærernes praksis får lov at gøre en forskel for det, vi som arbejdsmiljøforskere kan tænke om den. 


\section{NOTER}

1. AMICA: Arbejdsmiljøløsninger i callcentre gennem benchmark og netværk.

LEANUS: Lean uden stress.

2. TRIPS er et samarbejde mellem NFA (projektledelse), DTU og Copenhagen Business School og er finansieret af arbejdsmiljøforskningsfonden.

3. I denne artikel skriver vi primært, at fokus er lærernes trivsel. Trivsel skal dog i denne sammenhæng forstås som et forhold mellem trivsel og produktivitet; at det ikke giver mening for medarbejderne at tale om trivsel som noget uafhængigt af deres muligheder for at gøre et godt stykke arbejde. Se Andersen et al. 2008 og Sørensen et al. 2007.

4. I TRIPS-projektet undersøger vi betydningen af ændringer i ledelsesformer, ændringer i opfattelser af medarbejderen og ændringer i selve arbejdets indhold ved at analysere selvledelse som en katalysator for trivsel og produktivitet.

5. Med særlig henvisning til hvordan visualiseringsteknologier har haft konsekvenser for kvinder i medicinen, har forfattere som Evelyn Fox Keller, Donna Haraway, Sarah Franklin og Monica Casper slået fast, at det at gøre noget synligt i sig selv er en intervention eller et eksperiment. Man kan så at sige ikke "kigge uden at pille". (Fox-Keller 1996). Et yndet og illustrativt eksempel er Lennart Nilssons bog: Et barn bliver til, som ved sin udgivelse viste nogle af de første vellykkede fotos af barnets udvikling i livmoderen. Det, der tilsyneladende kan virke som et uskyldigt blik ind i et aspekt af livet, som verden endnu ikke har haft adgang til, får ifølge Sarah Franklin og Monica Casper konsekvenser for den måde, vi behandler fostre og mødre på i medicinsk praksis. I Lennart Nilssons smukke fotografier sker der en omvending af forholdet mellem moderen og barnet inden for medicinen (Franklin 1991). Hvor moderen før blev betragtet som det primære menneskelige subjekt, hvis rettigheder og helbred medicinen har til opgave at beskytte, bliver hun i takt med udviklingen af visualiseringsteknologier reduceret til det sorte passepartout udenom et lille levende subjekt, som nu pludselig får nye rettigheder. Det er ifølge Sarah Franklin ikke tilfældigt, at det netop er Lennart Nielssons fotografier, der pryder 80'ernes anti-abort og 'right to life' kampagner i USA og UK (Franklin 1991).

\section{RefERENCER}

Allvin, Michael \& Gunnar Aronsson (2003): The Future of Work Environment reforms: Does The Concept of Work Environment Apply within The New Economy?, i International Journal of Health Services, 33, 1, 99-111.

Andersen, Vibeke, Pia. Bramming \& Flemming Nielsen. (2008): Arbejdsmiljø for fremtiden, rapport i serien Øje for Arbejdsmiljø, LO.

Barad, Karen (2003): Posthumanist Performativity: Toward an Understanding of How Matters Comes to Matter, i Journal of Women in Culture and Society, 28, 3, 801-831.

Bourdieu, Pierre (1997): The Logic of Practice, Oxford, UK, Polity Press.

Bramming, Pia \& Christine Mølgaard Frandsen (2003): Iagttagelsens praksis - strategi for udvik- ling og kompetence, Frederiksberg, Samfundslitteratur.

Demant, Jacob (2005): Fokusgrupper: Spørgsmål til fænomener i nuet, i Dorthe Staunæs \& Dorthe Marie Søndergaard (red.): Kvalitative metoder i et interaktionistisk perspektiv, København, Hans Reitzels Forlag.

Despret, Vinciane (2005): Sheep Do Have Opinions, i B. Latour \& P. Weibel (red.): Making Things Public - Atmosphere of Democracy, Cambridge, MIT Press.

Foucault, Michel. (2004): Brugen af nydelserne seksualitetens historie 2, Frederiksberg, Det lille forlag.

Fox-Keller, Evelyn (1996): Future Natural: Nature, Science, Culture, London, Routledge. 
Franklin, Sarah (1991): Fetal Fascinations: New Dimensions to The Medical Scientific Construction of Fetal Personhood, i S. Franklin, C. Lury \& J. Stacey (red.): Off-Centre - Feminism and Cultural Studies, Birmingham, Harper Collins Academic, 190-204.

Gomart, Emilie (2004): Surprised by Methadone: in Praise of Drug Substitution Treatment in a French Clinic, i Body \& Society, 10, 2-3, 85-110. Grønbæk, Justine Pors (2009): Evaluering indefra. Politisk ledelse af folkeskolens evalueringskultur, Frederiksberg, Nyt fra Samfundsvidenskaberne.

Halkier, Bente (2008): Fokusgrupper, Frederiksberg, Samfundslitteratur.

Haraway, Donna J. (1991): Simians, Cyborgs and Women - The Reinvention of Nature, London, Routledge.

Harper, Douglas (2002): Talking about Pictures: A Case for Photo Elicitation, i Visual Studies, 17, 1, 13-25.

Hurdley, Rachel (2007): Focal points: Framing Material Culture and Visual Data, i Qualitative Research, 7, 3, 355-374.

Jävinen Margreta \& Nanna Mik-Meyer (2005): Kvalitative metoder i et interaktionistisk perspektiv, København, Hans Reitzels Forlag.

Kaiser, Stephan Gordon Müller-Seitz, Miguel Pereira Lopes \& Miguel Pina e Cunha (2007): Weblog-Technology as a Trigger to Elicit Passion for Knowledge, i Organization, 14, 2, 391-412.

Karasek, Robert A. (1979): Job Demands, Job Decision Latitude, and Mental Strain: Implications for Job Redesign, i Administrative Science Quarterly, 24, 285-308.

Latour Bruno (2005): Reassembling the social, Ox- ford, Oxford University Press.

Limborg, Hans Jørgen (2002): Den risikable fleksibilitet - På vej mod et "nyt" arbejdsmiljø, København, Frydenlund.

Olesen, Kristian Gylling, Anders Bojesen \& Pia Bramming. (2009): I'm a professional teacher, why don't you trust me - the ambiguous struggle for professionalization in the Danish public sector. The 6th International Critical Management Studies Conference, July 13-15, 2009. Warwick Business School, the University of Warwick, UK.

Pedersen, Michael (2008): Tune in, break down, and reboot - new machines for coping with the stress of commitment, i Culture and Organization, 2, 14, 171-185.

Rose, Nicolas (1999): Governing The Soul - The Shaping of The Private Self, London/New York, Free Association Books.

Semmer, Norbert K. (2006): Job stress interventions and the orgnization of work, i Scand J Work Environ Health, 32, 6, 515-527.

Sørensen, Ole Henning, m.fl. (2007): Arbejdets kerne. Om at arbejde med psykisk arbejdsmiljø $i$ praksis, København, Frydenlund.

Tynell, Jesper (2002): "Det er min egen skyld" nyliberale styringsrationaler indenfor Human Ressource Management, i Tidsskrift for Arbejdsliv, 4, 2.

Warren, Samantha (2002): "Show Me How it Feels to Work Here": Using Photography to Research Organizational Aestetics, i ephemera -critical dialogues on organization, 2, 3, 224-245.

Warren, Samantha (2008): Empirical Challenges in Organizational Aesthetics Research: Towards a Sensual Methodology, i Organization Studies, 29, 4, 559-580.

Pia Bramming, cand.merc., ph.d. er Seniorforsker ved Det Nationale Forskningscenter for Arbejdsmiljø

e-mail:pbr@nrcwe.dk

Birgitte Gorm Hansen, cand.psyk., er ph.d.-stipendiat ved Copenhagen Business School, Institut for Ledelse, Politik og Filosofi

Kristian Gylling Olesen, cand.merc.fil., er ph.d.-stipendiat ved Det Nationale Forskningscenter for Arbejdsmiljø

e-mail:kgo@nrcwe.dk 